\title{
Advancing entrepreneurship as a design science: developing additional design principles for effectuation
}

\author{
Stephen X. Zhang • Elco Van Burg
}

Accepted: 13 March 2019 / Published online: 8 June 2019

(C) The Author(s) 2019

\begin{abstract}
Scholars have advocated the development of entrepreneurship as a design science. One foundational challenge in a design science is to identify design principles. We argue that a particular field can draw on a design knowledge from different design sciences to develop design principles. In particular, we show that entrepreneurship research can learn from one branch of artificial intelligence studies called "genetic algorithm," which is a design field that creates solutions for complex, nonanalytical, and ill-structured problems. We illustrate the analogous transfer process by identifying complementary design principles for one exemplary entrepreneurship theory, namely effectuation. In turn, these additional effectual design principles further effectuation theory as a design science and help advance entrepreneurship as a nascent design science.
\end{abstract}

The authors are indebted to David Goldberg, the pioneer of genetic algorithms. David inspired this paper and helped the R\&R process invaluably. Next to that, we thank special issue editor Martin Obschonka, the anonymous reviewers, as well as Joep Cornelissen, Dimo Dimov and seminar partipants at the 2016 Effectuation Conference in Bodø for their comments on earlier versions of this study.

S. X. Zhang ( $\bowtie)$

The University of Sydney, Rm 4229, H70 - Abercrombie Building, Sydney, NSW 2006, Australia

e-mail: stephen.zhang@sydney.edu.au

E. Van Burg $(\bowtie)$

Vrije Universiteit Amsterdam, Amsterdam, The Netherlands e-mail: j.c.van.burg@vu.nl
Keywords Design science $\cdot$ Effectuation $\cdot$ Genetic algorithms $\cdot$ Analogous transfer

JEL classifications A12 $\cdot$ L2 $1 \cdot$ L22 $\cdot$ L26 $\cdot$ L29 $\cdot$ M13 . $\mathrm{O} 32 \cdot \mathrm{O} 31$

\section{Introduction}

Scholars have advocated that entrepreneurship research needs to be developed as a design science, in order to increase a focus on relevant (design) questions and to help with developing practical tools for managers (e.g., Jelinek et al. 2008; Romme 2003; Van de Ven 2007). In contrast to descriptive and explanatory sciences, design sciences focus on the process of making choices on what is possible and useful for the creation of possible futures, rather than on what currently prevails (Hevner et al. 2004; Romme 2003). For instance, design sciences bear the promise that they can help understand and provide guidance on how entrepreneurs design their ventures (Dimov 2016; Sarasvathy 2003; Venkataraman et al. 2012). Entrepreneurs are frequently confronted with such design choices (e.g., Baron et al. 1999), which carry significant consequences for their ventures (Baron et al. 2001; Wasserman 2012). Therefore, researchers have called to study the general design principles in the processes of designing new ventures (Dimov 2016; Romme and Endenburg 2006; Sarasvathy 2003).

Despite repeated calls to study entrepreneurship as a design science, several authors have argued that 
progress has been limited (i.e., Dimov 2016; Pandza and Thorpe 2010; Selden and Fletcher 2015), especially with regard to developing theoretically sound and practically relevant design principles (Berglund et al. 2018). Design principles prescribe possible changes to achieve certain aims (Baldwin and Clark 2000; Romme and Endenburg 2006) in the form of pragmatic heuristics that explain that "to achieve $\mathrm{Y}$ in situation $\mathrm{Z}$, then something like action X will help" (Van Aken 2004, p. 227). The identification of such design principles is a foundational task for the development of a design science (Parrish 2010; Romme 2003; Van Aken 2004).

Researchers can develop design principles through research synthesis (Denyer et al. 2008) and by codifying practitioners' tacit knowledge (e.g., Romme and Endenburg 2006; Van Burg et al. 2008). We propose a different and novel approach, which seems promising to develop management scholarship from a design science perspective. We propose to develop design principles through "analogous transfer" (Cornelissen and Durand 2014) from distant disciplines. As Oswick et al. (2011) and Cornelissen and Durand (2014) argued, analogies are one of the important ways to advance theory building, and here we in particular demonstrate that entrepreneurship can be advanced as a design science-and other management disciplines by the same token-by intentionally transferring design principles from other design sciences.

To demonstrate the development of design principles through analogous transfer, we focused on further developing the theory of effectuation (Sarasvathy 2001, 2003), which already has a number of design science characteristics and we show that transferring design principles from the design sciences of artificial intelligence (AI), in particular, genetic algorithm, is very promising. In terms of designing, we can learn a lot from AI designers, as they typically engage in frequent and rapid design cycles. AI designers design AI algorithms and solutions typically within a few days or months and would have worked on a range of design problems or challenges. For a single problem, an AI designer would design a multitude of AIs to see which one works well. Next, what worked well in previous challenges will be synthesized as design principles and borrowed to tackle new design challenges. Therefore, AI is a great field to learn from in terms of crosspollinating tested and proven design principles.

We selected the field of genetic algorithms to borrow design principles from through a process of analogous transfer. Genetic algorithm, inspired by genetic evolution, is one of the early and most established branches of AI. A genetic algorithm mimics how nature designs without "specifying in advance all the features of a problem and the actions" and its assumptions and causal structure fit well with key characteristics of entrepreneurship (Read et al. 2016). In fact, others have already applied genetic algorithms to organization design (e.g., Bruderer and Singh 1996; Rivkin and Siggelkow 2003) and have prompted to view entrepreneurship through a genetic algorithm lens as well (Cavarretta and Furr 2013).

Thus, this study substantiates the research agenda to further entrepreneurship research as a design science, by developing theoretically and practically relevant design principles. Accordingly, this study illustrates an alternative approach for developing design principles by using a process of analogous transfer from other design sciences. The additional design principles provide guidance to key design questions that confront scholars and practitioners.

\section{Furthering design sciences through analogous transfer}

Several studies have advocated advancing entrepreneurship as a design science (e.g., Dimov 2016; Selden and Fletcher 2015; Venkataraman et al. 2012). The origins of design science go back to the 1960s (Cross 2001), when visionary Buckminster Fuller called for a "design science revolution" using science, technology, and design to overcome human and environmental problems (Fuller 1969). According to Fuller (n.d.), "Science sets in order the facts of experience. Design (...) is that which you do deliberately. Using principles, then, employing order, we try to anticipate the needs of humanity, anticipate the needs of nature in general, (...) using those principles then to actually begin to participate in the evolutionary formulations of nature." Despite the scientific basis of design, design methodologists early on attempted to clarify the differences between science and design. For instance, Herbert Simon contrasted design science (e.g., engineering, architecture, medicine, artificial intelligence) with classical scientific methods (e.g., physics, social sciences) that aim at description and explanation. In contrast, a design science, also called a science of the artificial, aims to provide guidance on designing possible futures, 
focusing on what might be or what people can do (Simon 1969/1996). Applied to entrepreneurship, mainstream science answers descriptive and explanatory questions, such as "How do entrepreneurs develop a business model?", whereas design sciences ask "How can entrepreneurs develop business models?" Thus, design sciences focus on what is possible and useful for the creation of the future rather than what currently prevails (Hevner et al. 2004; Romme 2003). Table 1 compares the scientific method with design science and entrepreneurship, drawing on Sarasvathy and Venkataraman (2011) and Van Burg and Romme (2014).

Besides having a different purpose, design science and the "natural" scientific method also differ in the type of knowledge and thinking, and the key mechanisms (see Table 1). The scientific method aims at providing description and explanation, ideally resulting in tested propositions. Key mechanisms for the scientific method are data gathering, formal modeling, quantitative analysis, and hypothesis testing (Sarasvathy and Venkataraman 2011). In contrast, a design science has a pragmatic perspective to develop knowledge that is helpful and actionable (Van Burg and Romme 2014). To facilitate the design process, central mechanisms include the codification of existing design solutions (e.g., Van Burg et al. 2008), decomposing those solutions, subsequently recombining and synthesizing them into design principles and new design solutions (Baldwin and Clark 2000; Romme and Endenburg 2006) while drawing on scientific knowledge (Luo 2015).

Recent work in entrepreneurship has acknowledged that design is at the core of the entrepreneurial process (e.g., Dimov 2016; Sarasvathy 2003, 2004), as entrepreneurs use design logic in creating new artifacts- asking "how to" rather than "what" questions - and try to utilize contingencies and control dependencies along the way (Sarasvathy 2008). Studying entrepreneurship as a design science not only provides practical helps for entrepreneurs but also can result in new and fresh insights into long-standing debates (Berglund et al. 2018; Dimov 2016). In other words, the development of entrepreneurship as a design science is not only relevant to teach entrepreneurial skills (Garbuio et al. 2017), or to guide them in the design of their endeavors, but also to advance theories by probing the mechanisms through with actions result in particular outcomes (Denyer et al. 2008; Van Burg and Romme 2014).

To develop entrepreneurship as a design science, researchers have pointed at the crucial role of design principles (e.g., Denyer et al. 2008; Romme 2003; Van Aken 2004). Design principles serve as "instruments" to gain and provide insight into the design process (Dimov 2016), as they provide key levers for designing solutions for complex problems. Design principles convert tacit and complex knowledge of the venture design into explicit, manageable, and actionable knowledge to (re)create new ventures (Romme 2003; Van Aken 2004). For instance, to mention a couple of important examples in the entrepreneurship literature, Sarasvathy $(2001,2008)$ has outlined the principles that follow an effectual design logic, Garud et al. (2006) have identified the principles underlying the emergent organization design of Infosys Technologies, and Van Burg et al. (2008) codified design principles for entrepreneurship within university environments.

To develop such design principles, researchers have recommended collecting insights from practitioners (e.g., Garud et al. 2006; Plsek et al. 2007; Romme and Endenburg 2006) as well as synthesizing existing

Table 1 Comparing science, design, and entrepreneurship

\begin{tabular}{|c|c|c|c|}
\hline & Scientific method & Design science & Entrepreneurship \\
\hline Purpose & $\begin{array}{l}\text { Understand phenomena by } \\
\text { discovering general "laws" } \\
\text { based on empirical data. }\end{array}$ & $\begin{array}{l}\text { Develop guidance to create artifacts, } \\
\text { for instance by refining or } \\
\text { developing design principles. }\end{array}$ & $\begin{array}{l}\text { Create value and newness by } \\
\text { engendering new ends and } \\
\text { improving existing solutions. }\end{array}$ \\
\hline $\begin{array}{l}\text { Knowledge and } \\
\text { thinking }\end{array}$ & $\begin{array}{l}\text { Descriptive and explanatory } \\
\text { thinking. }\end{array}$ & $\begin{array}{l}\text { Pragmatic knowledge that is } \\
\text { synthesized to get helpful } \\
\text { prescriptions. }\end{array}$ & $\begin{array}{l}\text { Imaginative thinking informed } \\
\text { by a variety of (embodied) } \\
\text { knowledge to create new and } \\
\text { transform existing artifacts. }\end{array}$ \\
\hline Key mechanisms & $\begin{array}{l}\text { Gathering data, modeling } \\
\text { situations, analyzing, and } \\
\text { testing. }\end{array}$ & $\begin{array}{l}\text { Codifying solutions, decomposing, } \\
\text { recombining, and synthesizing } \\
\text { elements. }\end{array}$ & $\begin{array}{l}\text { Action, interaction, reaction, } \\
\text { transformation, and co-creation. }\end{array}$ \\
\hline
\end{tabular}


insights from the body of literature (e.g., Denyer et al. 2008; Tranfield et al. 2003; Van Burg and Romme 2014). We propose an alternative approach, as we aim to perform analogous transfer (cf. Cornelissen and Durand 2014) of design principles and adopt related insights from a more distant field. We argue that design principles can be borrowed and transferred from other fields which share key assumptions, as a way of creating analogies from distant disciplines, but with a specific and shared focus (Oswick et al. 2011). We selected the field of genetic algorithms as a candidate for analogous transfer, because genetic algorithms, and artificial intelligence in general, often borrow design principles from each other (cf. Miller et al. 2002). Moreover, genetic algorithms share key features with entrepreneurship. We first introduce genetic algorithms and then discuss the similarities to the field of entrepreneurship.

\section{Genetic algorithms and entrepreneurship}

The field of genetic algorithms started in the 1950s as one of the foundational artificial intelligence methods to solve design problems in a nondeterministic manner. A genetic algorithm develops "search procedures based on the mechanisms of natural selection and genetics" (Goldberg 2002, p. 2). Genetic algorithms are popular as an AI method in the areas of computing and engineering (Chaudhry and Luo 2005; Zang et al. 2010) and perform better than models with rational agents in explaining economic patterns (Arifovic 1995).

To perform analogous transfer between genetic algorithms and effectuation, we briefly examine the process steps and the most essential design principles in genetic algorithms. These design principles rely on the four elementary artificial evolution steps of genetic algorithms: initialization, selection, variation, and retention (Goldberg 2002).

\subsection{Initialization}

To initialize solutions, genetic algorithms begin with a population of building blocks (also called "solutions" or "means") (Davis et al. 2007; Goldberg 1989; Holland 1975). Building blocks are the smallest elements that can be mutated or exchanged. Building blocks in entrepreneurship might refer to the parts of a marketing channel or the elements of a business model. The genetic analogue for a building block is a chromosome or meme, a discrete package of knowledge in the form of concepts (Henrich et al. 2008; Heusinkveld et al. 2013), that is either current or imagined. Certain combinations of building blocks constitute organizations that interact with the environment, just as particular combinations of genes form phenotypic expressions that define the biological organisms that interact with the natural world. While an entrepreneur typically has a limited set of means at hand (building blocks), he or she also has a much larger population of means that compete for attention in his or her mind. The set of means the entrepreneur uses to make decisions includes both these real and imagined means (see Dolmans et al. 2014). The initial population of building blocks can be created randomly or by leveraging the prior knowledge of potentially helpful building blocks.

\subsection{Selection}

The population of building blocks undergoes evaluation, such that good building blocks are selected. The selection occurs stochastically, based on the building blocks' relative fitness for the context or purpose. For example, a particular relationship with a supplier as an element in a business model might be selected because it fits the industrial or market context. Selection mechanisms could involve mathematical models, simulations, human heuristics (i.e., let humans intuitively choose building blocks), or some combination thereof.

\subsection{Variation}

Variation often involves mutating building blocks or combinations of building blocks. Existing combinations are decomposed into the constitutive building blocks and then recombined to create new combinations (Holland 1975). In genetic algorithm terms, recombination selects genes (i.e., building blocks) from parent chromosomes (i.e., the current combination of building blocks) and creates new offspring. In addition to recombination, mutations take place. Mutation randomly changes the new offspring, and this helps prevent solutions from rendering a local optimum.

\subsection{Retention}

Retention is the process by which the new population of building blocks and the combinations they constituteresulting from selection and variation-replaces the 
original population. According to evolutionary theory, venturing endeavors or effectual experimentations are bundles of ideas and practices, retained in evolutionary processes, such that those that are not retained do not survive.

All four steps (initialization, selection, variation, and retention) can be done by humans (Kosorukoff 2001). In such human-based genetic algorithms, humans can use their creativity, judgment, and intuition to create, alter, and select solutions without spelling out their decision criteria. Human-based genetic algorithms have designed among others advertisements, music, and architecture, by letting humans contribute directly in any of the four steps (Cheng and Kosorukoff 2004; Ren et al. 2014; Takagi 2001).

Based on these four elementary steps, researchers, in decades of works on genetic algorithms, have identified important design principles (Goldberg 2000, 2002; Holland 1975). Goldberg (2002) cites seven key design principles for genetic algorithms:

1. Understand the building blocks of the design problem (initialization).

2. Decompose the design problem into building blocks (initialization).

3. Ensure an adequate initial supply of building blocks (initialization).

4. Set the right speed for selection decisions (selection).

5. Ensure the quality of the selection decisions (selection).

6. Facilitate variation and recombination (variation).

7. Ensure to retain better building blocks and deemphasize others (retention).

This procedure, guided by these design principles, iterates from selection to retention until reaching a terminating condition. The procedure grants successful variations a higher likelihood to survive and forms the basis for future variations, in an evolutionary manner (Andreoni and Miller 1995; Arifovic and Bullard 1997), such that the genetic algorithm gradually approaches satisfying solutions. Solutions are only satisfying because genetic algorithms perform guided but still random search processes, which cannot guarantee optimality of the solutions.

Genetic algorithms are particularly applicable for issues of organization design, as descriptors of how organizations and organizational forms get created, manipulated, and selected (Rivkin and Siggelkow 2003) and how organizations learn through experimentation and learning-by-doing (Davis et al. 2007). Many software companies use genetic algorithms to introduce variations gradually and deemphasize less successful lines of code. Similarly, in product development, genetic algorithms have been applied-for example, by Nokia - to introduce and generate new variants and combinations to make new products and to select iteratively the best-performing variants (Kreng and Lee 2004). Genetic algorithms also are used in a range of other design phenomena in management, such as the emergence of strategic groups (Lee et al. 2002) or the bargaining strategies of negotiators with complete or incomplete information (Zott 2002). For example, in organization design, Bruderer and Singh (1996) used genetic algorithms to explain that managers do not directly predict or design organizational forms but rather guide the evolutionary processes, such as by setting the rate of variation and the selection criteria.

From a genetic algorithm perspective, entrepreneurship is primarily a process in which variation is the rule rather than the exception (Aldrich and Martinez 2001). Entrepreneurs choose the initial pool of building blocks of ideas, resources, and processes in their new venture creations, determine how to increase or decrease variation, and devise how to make selection and elimination decisions (Crawford and Kreiser 2015; McKelvey 2004). Such design decisions can be guided by design principles to aid entrepreneurs in better designing new ventures, and these (additional) design principles can be borrowed from other design fields.

\section{Common ground enabling analogous transfer from genetic algorithms}

Entrepreneurship shares fundamental commonalities with genetic algorithms in creating new solutions. First, both entrepreneurship and genetic algorithms deal with difficult, complex problems that do not easily yield to predictions or analytical procedures, as the problems involve fundamental uncertainty known as "Knightian uncertainty." Knightian uncertainty exists when not only the distribution of risks is unknown but when also the risks themselves are unknown (Knight 1921). Second, both areas approach problems by transforming solutions gradually, in nonlinear and nonpredictive processes. Third, the processes to create new solutions mimic how evolution designs, that is, iteratively through the initiation-selection-variation-retention steps. Fourth, in 
Table 2 Comparing biological evolution, genetic algorithms, and effectuation

\begin{tabular}{|c|c|c|c|}
\hline & Biological evolution & Genetic algorithms & Effectuation \\
\hline Theory description & $\begin{array}{l}\text { Explains the process of change in } \\
\text { the biological populations over } \\
\text { successive generations. }\end{array}$ & $\begin{array}{l}\text { Prescribes how to design nonpredictive } \\
\text { search procedures by mimicking } \\
\text { biological evolution. }\end{array}$ & $\begin{array}{l}\text { Prescribes how entrepreneurs make } \\
\text { decisions under uncertainty by } \\
\text { engaging in a nonpredictive design } \\
\text { process that begins from means. }\end{array}$ \\
\hline \multicolumn{4}{|l|}{ Concepts } \\
\hline Individual & A genetic organism. & One among a population of solutions. & $\begin{array}{l}\text { A possible means among "who you } \\
\text { are, what you know, and whom } \\
\text { you } \\
\text { know." }\end{array}$ \\
\hline Building block & A chromosome. & $\begin{array}{l}\text { A meme, a discrete package of } \\
\text { knowledge. }\end{array}$ & $\begin{array}{l}\text { A means such as "who you are, what } \\
\text { you know, and whom you know." }\end{array}$ \\
\hline Population size & $\begin{array}{l}\text { The total amount of available } \\
\text { chromosomes. }\end{array}$ & The amount of breeding solutions. & The amount of means at hand. \\
\hline Decomposition & $\begin{array}{l}\text { Biological evolution theory runs } \\
\text { autopilot and hence does not } \\
\text { specify decomposition } \\
\text { intentionally. }\end{array}$ & $\begin{array}{l}\text { Humans design rules to break up } \\
\text { solutions into subsolutions to } \\
\text { increase the likelihood } \\
\text { of finding good solutions. }\end{array}$ & $\begin{array}{l}\text { Effectuation mentions decomposition } \\
\text { but does not specify how } \\
\text { decomposition could work. }\end{array}$ \\
\hline Selection criteria & Environmental selection. & $\begin{array}{l}\text { Humans design the criteria to } \\
\text { determine why certain solutions } \\
\text { are preferred to others. }\end{array}$ & $\begin{array}{l}\text { Criteria to select good solutions, } \\
\text { guided by the affordable loss } \\
\text { principle. }\end{array}$ \\
\hline $\begin{array}{l}\text { Rate of } \\
\text { elimination }\end{array}$ & $\begin{array}{l}\text { The speed of eliminating a } \\
\text { chromosome. }\end{array}$ & $\begin{array}{l}\text { Humans design the speed of } \\
\text { eliminating solutions. }\end{array}$ & $\begin{array}{l}\text { Effectuation has yet to cover } \\
\text { elimination } \\
\text { speed. }\end{array}$ \\
\hline Rate of change & The speed of mutation/crossover. & $\begin{array}{l}\text { Humans design the speed of } \\
\text { introducing changes to the } \\
\text { solutions. }\end{array}$ & $\begin{array}{l}\text { Effectuation has yet to cover rate } \\
\text { of change. }\end{array}$ \\
\hline Selectivity & Harshness of the environment. & $\begin{array}{l}\text { Humans design the standards } \\
\text { on selection of solutions. }\end{array}$ & $\begin{array}{l}\text { The standards on selection are } \\
\text { idiosyncratic. }\end{array}$ \\
\hline \multicolumn{4}{|l|}{ Processes } \\
\hline Initialization & $\begin{array}{l}\text { Initialization is not a common } \\
\text { reoccurring phenomenon in } \\
\text { biological evolution. }\end{array}$ & $\begin{array}{l}\text { Human design how to start the } \\
\text { first generation of solutions. }\end{array}$ & $\begin{array}{l}\text { The process of deciding which } \\
\text { means to start with. }\end{array}$ \\
\hline Selection & $\begin{array}{l}\text { The differential survival and } \\
\text { reproduction of individuals as a } \\
\text { result of environmental factors. }\end{array}$ & $\begin{array}{l}\text { Human design the principles to } \\
\text { choose which individuals will } \\
\text { survive. }\end{array}$ & $\begin{array}{l}\text { The process of preferring certain } \\
\text { means to others. }\end{array}$ \\
\hline Variation & $\begin{array}{l}\text { Crossover of and mutation to the } \\
\text { genes. }\end{array}$ & $\begin{array}{l}\text { Human design the principles to } \\
\text { conduct crossover and } \\
\text { mutation to the individuals } \\
\text { to generate new ones. }\end{array}$ & $\begin{array}{l}\text { The process of introducing changes } \\
\text { to the population of means. }\end{array}$ \\
\hline Retention & $\begin{array}{l}\text { The process where the new } \\
\text { individuals replace the old } \\
\text { population. }\end{array}$ & $\begin{array}{l}\text { Human design how the new } \\
\text { individuals - resulting from } \\
\text { selection and variation-replaces } \\
\text { the old individuals. }\end{array}$ & $\begin{array}{l}\text { The process by which new means } \\
\text { replace the original means. }\end{array}$ \\
\hline
\end{tabular}

contrast with a biological evolution, both entrepreneurs and genetic algorithm designers exhibit individual agency to design through high-level principles (Cavarretta and Furr 2013).

In entrepreneurship, effectuation theory in particular shares commonalities with genetic algorithms because of their shared roots in design sciences. Table 2 presents an overview of key genetic algorithm terms, connected with effectuation theory, and contrasted to biological evolution. Effectuation consists of a set of observed heuristics or principles that expert entrepreneurs leverage to design their new ventures (Sarasvathy 2001). Effectuation theory proposes that many of those entrepreneurs design new ventures not by predicting the future but by beginning with what they know or have and then introducing variations by using design 
principles that guide and control their endeavors (Sarasvathy 2003). In this process, the entrepreneurs remain in control, even though they lack a clear understanding from the outset and cannot predict the expected returns of their courses of actions (Wiltbank et al. 2006). As such, these entrepreneurs engage in a process of opportunity creation rather than opportunity discovery (Alvarez and Barney 2007), as they shape their opportunities along the way, while simultaneously learning what the opportunity is that is taking shape under their hands. In this sense, both genetic algorithms and effectuation theory explicitly depart from competing theories in their respective fields. Newness is not created by setting goals and undertaking subsequent analyses; rather, the design of new ventures begins with who the entrepreneurs are, what they know, and whom they know, and then proceeds with their iterations. In genetic algorithms, solutions similarly come about by intentionally adjusting or manipulating what already exists in the population, which thus deviates from biological evolution.

Genetic algorithms and effectuation theory also tackle complex problems similarly by inducing gradual variations. Effectual entrepreneurs start with their means combined with a general purpose; as they proceed, they continuously evaluate and change their course by introducing variations and negotiating their actions with the "outside" world (Sarasvathy 2001). Stemming from these means, effectual entrepreneurs create variations, guided by certain simple rules (Dew et al. 2018). Many variations, created during the process by the entrepreneur, persist only as temporary ideas, mental exercises, or small-scale experiments, rather than living long enough to become part of the venture. Most variations do not increase fitness directly, but a few successful variations are selected and retained and may become new norms. This process of creation, mimicking evolution through variation and selection, characterizes both genetic algorithms and effectuation. For example, in effectuation terms, an entrepreneur explores what he or she can do with the means and then gradually builds a venture by engaging in experiments, often with trusted partners (Sarasvathy 2003; Sarasvathy et al. 2010; Sarasvathy and Dew 2005).

Yet, despite all these similarities, genetic algorithms remain one of the most notable but underemployed fields to advance entrepreneurship as a design science, perhaps due to its deep roots in design studies and its nonpredictive, nonlinear approach. Even so, the very reasons that genetic algorithms might have been underused also are essential characteristics of effectuation and entrepreneurship in general. Sarasvathy (2001) calls explicitly for research to connect nonlinear and nonpredictive design theories with effectuation, given their similarities. From the outset, Sarasvathy (2001) posited that effectuation is a set of principles for designing entrepreneurial artifacts in the design science tradition of Herbert Simon. Yet, without further developing these principles, the challenges to fully develop effectuation as a design science for "what can be" remain daunting and opaque (cf. Perry et al. 2012). Complementary design principles are particularly required to guide selection and variation mechanisms. Such additional principles would serve as science-based tools for entrepreneurs to make future-oriented choices and as guides to fruitful areas of research (Berglund et al. 2018; Van Burg et al. 2008).

Over more than a decade of development, effectuation literature has identified the following design principles (Sarasvathy 2001; Wiltbank et al. 2009):

1. Principle 1 (bird in hand): Start with your means: who you are, what you know, and whom you know.

2. Principle 2 (affordable loss): Decide on the basis of what you can afford to lose instead of expected returns.

3. Principle 3 (crazy quilt): Form and obtain precommitments from partnerships.

4. Principle 4 (lemonade): Leverage both uncertainties and contingencies.

5. Principle 5 (pilot-in-the-plane): Rely on human agency to maneuver rather than on exogenous factors, such as technological trajectories.

Each of these effectuation principles prescribes a heuristic for tackling hard problems in a complex solution space under uncertainty. They share the aspiration of exploiting locality and contingency in the evolution of an artifact rather than predicting the best artifact in advance (Sarasvathy 2003). These principles also are not passive deployments and redeployments of resources purely in response to simple signals (cf. Augier and Teece 2009); instead, they are purposeful and intentional (Matthews 2009).

Finally, even with these fundamental commonalities, no prior studies have applied design principles of genetic algorithms to advance entrepreneurship as a design science. Yet the opportunity to borrow from such a discipline is promising. Therefore, we now turn to a discussion of which complementary design principles can be 
developed by examining what the field of genetic algorithms as a more established design science can offer.

\section{Identifying complementary effectual design principles}

As an illustration of the need to develop additional design principles for effectuation, consider Myra, who reads Sarasvathy's (2008) book on effectual entrepreneurship carefully before setting out to open an Indian restaurant by effectuating her means. To begin, Myra tries to determine her means: She has no prior experience in the restaurant business, and her cooking is not great. Still, several of her friends are known for their good home cooking and have expressed interest in working as chefs. Myra also knows a few restaurant owners who might lend her a hand. Myra wants to innovate but is not sure how to integrate high-tech into her restaurant idea. Still, these angel investors could introduce her to other investors who are more interested in restaurants. Last, but not least, Myra knows that one of her most important means is her charming personality, which can easily land her a temporary job in other restaurants to gain experience.

As Myra jots down her available means, she realizes she has more than one available means, so must decide which means are good for effectuating with. Is it better to effectuate with few or many means? As she ponders further, increasingly more questions arise, causing her to feel unguided on how to use effectuation to design a new venture. She learned about (stakeholder) selfselection of means, as well as the affordable loss principle in constraining how means are put to work, but would these principles be sufficient in her case? As the new venture evolves, how should she select which variations to retain and which to put aside? As means are not static, how can she facilitate change?

Myra's story illustrates how existing principles of effectuation might need augmentation in order to address many key design decisions in reality, in particular the selection and variation decisions. To relate genetic algorithm principles to effectuation theory, we closely reviewed classic and recent articles on the development of effectuation and identified the areas in which insights from genetic algorithms can help develop additional design principles (e.g., Arend et al. 2015; Chandler et al. 2011; Chiles et al. 2008; Fisher 2012; Jiang and Rüling 2018; Perry et al. 2012; Read et al. 2016; Read and Dolmans 2012). Next, we present four complementary effectuation design principles that provide guidance on designing variety and selectivity.

5.1 Initialization: effectuate from what you have (what is good to have?)

The effectuation process begins with the first principle of effectuation of "who you are, what you know, and whom you know" (Sarasvathy 2001, p. 258), resembling the means at hand. Starting with these means a general aspiration is formed that takes shape through cocreation with committed stakeholders (the third effectuation "crazy quilt" principle) resulting in the convergence of ideas and the emergence of more specific goals (Sarasvathy and Dew 2005). Yet, as entrepreneurs often have a repertoire of contacts and knowledge, they must discern which means serve as good starting points, among all means they might procure (Fisher 2012). Although effectuation theory highlights the key role of means, it does not specify the composition of the set of means. Still, entrepreneurs evaluate alternative means and adjust their means in relation to environmental constraints (Sarasvathy 2001; Sarasvathy and Dew 2005). Therefore, guidance on what means would be good to have in the first place may be helpful (cf. Arend et al. 2015; Chiles et al. 2008; Read and Dolmans 2012).

Viewed through the lens of genetic algorithms, effectuation begins with the building blocks of which entrepreneurs have control (Sarasvathy (2003) also uses the term of building blocks). The key building blocks include knowledge and experience-related elements, such as ideas, beliefs, assumptions, values, interpretative schema, and know-how, as well as available and potential relationships and pre-commitments (for a review of potential building blocks or "units of selection," see Breslin 2008). The building blocks of earlier start-ups and other career experiences (Engel et al. 2017) are passed on and recombined through the experience and knowledge of founders, employees, customers, investors, and other stakeholders.

Building blocks, therefore, are critical design elements. Yet, in both genetic algorithms and effectuation, designers cannot predict how good the building blocks will perform because of the uncertainty about both the environment and the fit with the building blocks. There is no deterministic landscape against which an effectual designer can pitch the fitness of the (combinations of) building blocks. At the same time, the initial set of 
means and pre-commitments in combination with the effectuator's aspiration give a rough direction to the venture; this aspiration also provides initial coherency in the collection of building blocks. The unpredictability of the environment makes it impossible to pick building blocks deterministically. In such a situation, the genetic algorithm instead suggests creating a diverse population of building blocks (Goldberg 2002). Some of the most diverse building blocks in the population will undoubtedly fail, but they may contribute no less to the ultimate satisfying solutions by creating crossovers. Emphasizing effectuation notions of experimentation and failure, the creation of variety adds to the tendency in effectual thinking to go with existing, comfortable means and relationships.

Good building blocks are not static but rather serve as dynamic seeds for creating new and better building blocks, similar to biological seeds that easily break themselves to become plants. Following this logic, effectual "crazy quilting" with partners and stakeholders' pre-commitments serves as a good design principle to seed building blocks. In line with effectuation theory, the set of building blocks needs to be developed through trusted partnerships, which will practically limit the set of building blocks to what someone can handle in terms of collaborations. Some building blocks are more complementary than others. Good building blocks may evolve into valuable parts of business models and ventures, even if they do not pay off immediately (Sarasvathy et al. 2008). A genetic algorithm-based design process can begin without a minimum standard for any building block (Chattoe-Brown 1998); rather, this minimum standard refers to building blocks' diversity. As Dew et al. (2018) observed, expert entrepreneurs, in collaboration with their stakeholders, create more and more novel variations than experienced managers. Thus, based on insights from genetic algorithms as well as the findings of Dew et al. (2018), in effectuation, the variety of means might be more important than the sheer number of means.

Returning to our hypothetical example, Myra can benefit from starting with a varied set of means from her and her stakeholders: reaching out and experimenting with different contacts (friends who love to cook, investors, other restaurant owners), gaining a little experience with other restaurants that would lend her a hand, and using her personality to attract clients. Starting with such a diverse set of means is likely better than venturing with a set minimum standard for one particular means (e.g., find a restaurant job to learn for a predefined number of years).

An easy way to increase the diversity of building blocks is to increase the population size of those building blocks. According to the genetic algorithm, when populations are too small, they can lead to premature convergence and substandard solutions (Goldberg 2002), whereas when populations are too large, they can waste valuable time and resources. For effectuation, insufficient building blocks produce a highly localized search, whereas an excessively large population can result in thinly spread resources, scattered efforts, and the starvation of resources for good building blocks. Thus, we expect an inverted U-shaped relationship between the size of the population of building blocks and design fitness, which is, however, unique for each venture. In the same population, diverse and complementary building blocks work better than overlapping ones. In Myra's situation, although she has no prior restaurant experience and is not a good cook herself, starting with all her available means would be too much, so the resulting effectual design would suffer. If she began with just one means - for example, a particular friend who loves cooking - she may end up with a restaurant far from the best she could have developed.

Design principle 1: Gather more than just a few means; at the same time, it is more important to have more diverse means than merely more means.

\subsection{Selection: selection criteria for building blocks}

Because building blocks are not static, design principles must be in place to ensure that the better building blocks grow and take over a dominant share of the population in the effectuation process. Whereas in biological evolution selection is mainly attributed to environmental forces (Hodgson 2013), in genetic algorithms and effectuation, the selection is predominantly driven by decision-makers. In organizational settings, building blocks compete for the attention of human beings (Ocasio 1997), implying that humans move on from certain building blocks if they stop noticing their public expressions, internalizing them, or reproducing them (Weeks and Galunic 2003). For example, new ideas or new procedures are put down if they are not remembered and enacted. 
In effectuation theory, the entrepreneur is the "pilot" who makes selection decisions in collaboration with committed stakeholders (Sarasvathy 2008). Thus, in this selection, the fitness of any particular means is subjective or intersubjective, not an objective given (Chiles et al. 2008; Dolmans et al. 2014). For effectual entrepreneurs, selection is an internal process of co-adaptation, involving their relevant stakeholders (Dew et al. 2018). Thus, the primary selection mechanisms are the direction set out by working with the set of means in view of a general aspiration and the co-creation processes with stakeholders. Yet, entrepreneurs might need more guidance in making selections, and thus, it is valuable to specify useful selection mechanisms that account for the uncertainty of the situation and lack of a predefined market environment that would determine the right fit.

The sense of whether something works or not in an individual's mind is explained in psychology by selfregulation theories, in particular control theories (e.g., Eccles and Wigfield 2002; Zimmerman 2002). These theories posit that individual entrepreneurs create a perception of the state of a variable of interest and compare the perception to a referent, which represents the desired state. The discrepancies between these two states determine the (lack of) fitness. The desired state is known in effectuation as a general aspiration (Sarasvathy 2008). In many cases, while it is hard to devise an algorithm for calculating the fitness of a design, it is relatively easy to tell the relative change in fitness (i.e., if a change increases or decreases the fitness). Similarly, Myra has a hard time to pinpoint the exact fitness score of a dish, say curry mutton, but she can tell relatively easily whether changing curry mutton to curry fish pleases more customers, and thus, she would be able to tell whether building blocks are fitness-reducing versus fitness-enhancing. As in genetic algorithms, what matters is the relative performance improvement instead of the exactitude of performance.

More importantly, because it is impossible to define perfect criteria to evaluate and select building blocks, due to dynamic uncertainty (Schmitt et al. 2018) about their future performance, designers of genetic algorithms focus on designing fast-and-frugal tests. Such fast-and-frugal tests are also essential for effectuation (Sarasvathy 2001, 2003) and widely recognized by practitioners, such as in the "lean start-up" movement (Ries 2011). Effectuation has one main design principle to guide selection, namely affordable loss, which prescribes that an entrepreneur should decide on the basis of what he or she can afford to lose (Dew et al. 2009; Sarasvathy 2008). Along this principle, we can identify other principles that guide selection based on genetic algorithm research, for example: running out of time, achieving sufficient quality, substantial convergence in the population (implying a decrease in diversity), and time elapsed since the last improvement.

If, for instance, we apply these design principles to choose alternative business model elements, we note that substantial convergence in the population could happen if, after some time, one or a few of these alternatives take off while others do not really gain traction. In practice, the elements that take off will attain consistent attention from the key stakeholders over time, and thus convergence will occur. In Myra's case, she starts with a little bit of everything-reaching out and experimenting with different contacts, gaining a little experience with other restaurants, and using her personality to attract clients for catering services. After doing this for 3 months, feedback from her main partners and clients points to the catering concept as critical. As such, the experimental trials converge into the catering concept as a building block to effectuate with, and as the catering consumes most attention, the other building blocks become less important. Thus, she has - unintentionally - reached substantial convergence in the population of building blocks.

Responding to calls to include time in the affordable loss principle (Dew et al. 2009), we point at the running out of time criterion which refers to the time someone can afford to test a certain solution, for instance allowing 2 months as an affordable period to validate an idea through customers. Using such rules, Myra tests the idea of working with a "wanna-be-chef" friend for 2 months, at the end of which Myra uses the market's responses to decide on the idea. Using the principle of achieving sufficient quality, entrepreneurs can similarly create simple rules, such as "Can we find two major buyers for the current service or product in three months?" Can Myra fill $50 \%$ of her restaurant tables in half a year? Finally, the time elapsed since last improvement criterion is again based on the time someone can afford, this time to come up with an improvement. It could lead to a simple rule, such as "If we cannot improve a certain technology after working on it for a year, we move on to other technologies" or "If we cannot find another key customer segment in two months, we have to change our approach." Practicing entrepreneurs, consciously or 
subconsciously, use such guiding principles, but these have not been recognized as design principles for guiding effectual decisions, nor have they been studied explicitly.

The preferences indicated by these tests do not require global knowledge and are not deterministic in nature (Sastry et al. 2005; Sastry and Goldberg 2003). Instead, these nondeterministic fast-and-frugal selection principles help to maintain a necessary level of diversity under conditions of fundamental uncertainty. These fastand-frugal tests do not assume existing markets or customer preferences but are low fidelity design principles for situations where entrepreneurs did not figure out their market yet, or in cases where entrepreneurs actually transform markets themselves (e.g., Dew et al. 2011; Sarasvathy and Dew 2005).

Design principle 2: Use one or more fast-andfrugal tests (i.e., substantial convergence in the population, sufficient quality, time elapsed since last improvement) to select appropriate building blocks for new venture creation.

\subsection{Variation: facilitating changes by decomposing}

The creation of variation, a crucial process in effectuation, occurs in collaboration with stakeholders, as specified in the third effectuation principle (Sarasvathy 2003, 2008; cf. Dew et al. 2018). As such, variations are not just a blind try but often guided by previous experience in a co-creating process (cf. Alvarez et al. 2013; Engel et al. 2017). New building blocks are introduced along the way by leveraging contingencies (the fourth effectuation principle "lemonade"). Dew et al. (2018) find that expert entrepreneurs create a greater range of variations than experienced managers do. These expert entrepreneurs also create variations based on their previous experience in addition to random variations (Sarasvathy et al. 2010). In a study on the creation of novelty through effectual transformations, Dew et al. (2011) found inductively that expert entrepreneurs mentioned a myriad of processes to introduce variations: deletion and supplementation, composition and decomposition, exaptation, manipulation, deformation, localization, prototyping, stereotyping, and free association. These variation processes, from an evolutionary view, are fundamentally generated by mutation and crossover of building blocks. Crossing over properly requires decomposition (Goldberg 2002), which reduces structural interdependencies and thereby allows for easy evolution (Simon 1969). Thus we emphasize here the process of composition, which is seen as an essential prerequisite of designing highperforming, enduring artifacts in effectuation theory (Sarasvathy 2003, 2008). Without decomposition, variation is limited, as faced by novice entrepreneurs (Sarasvathy et al. 2010). However, the role of iterative and continued decomposition is less obvious to nondesigners, remains underspecified (Sarasvathy and Dew 2005), and is often neglected (Sarasvathy 2008), so we elaborate specifically on the process of decomposition in effectuation.

Decomposition helps in two main ways. First, it helps to identify building blocks that can be changed, reused, and recombined, as described by the logic of exaptation that existing elements get co-opted for new roles (Dew et al. 2004). Different decompositions will surface distinct building blocks and thus enable distinct exchanges, leading to distinct exaptations. Second, decomposing helps to reveal the relationships and hence the interconnectedness among the building blocks in which the whole is greater than the sum of its parts.

To decompose better, genetic algorithms can provide some guidance. Different decompositions should be considered - as a thought exercise - to identify distinct sets of building blocks, some of which may evolve toward competent solutions better than others (Goldberg 2002). Empirical evidence confirms that good designers are those with the ability to find various representations of a design issue and the multitude of representations help them to solve hard problems (Goldberg 2002). Theoretically, such representations might include economic-financial representations (as found in accounting textbooks), real options theory (Kogut and Kulatilaka 2001; Vassolo and Anand 2008; Zhang and Babovic 2011), and dynamic capability views (Teece et al. 1997). The multitude of representations enable searches for new decompositions; those new decompositions can then help to reveal building blocks that are hard to find, deep, complex, integrated, and difficult to separate. Many capabilities, routines, and imprint effects are tough to reveal because they have developed tacitly, through years of experience. Without attempts to facilitate decomposition, designers can rely only on good luck to find good building blocks.

Myra thus might try a financial decomposition, which helps to reveal the costs, revenues, and margins 
and which, in the end, helps her realize that starting a conventional restaurant is too expensive. Therefore, she decides to start with an Indian-themed catering service, using the help from her friends who cook at home. Within a few weeks, the business has gained some success, especially catering to office parties that want to try something different. With such clients in mind, Myra drafts a simple flow diagram, drawn from a business model canvas, to decompose her business into its key building blocks: creating the menu, buying food and materials, preparing the food with key people, and serving the food. Finally, Myra asks a friend for input, who helps her decompose the capabilities in her new venture. Adding these different decompositions to her drawing board gives Myra different sets of building blocks that she can change to iterate her new venture. For example, she identifies that the process and capability of buying food and materials can be broken down and improved, and therefore, she engages more actively with a friend who knows a great deal about food and materials.

Design principle 3: Decompose by constructing multiple representations to identify building blocks and subsequently explore new combinations by exchanging building blocks.

\subsection{Retention: speed of updating building blocks}

Retention means deciding which new means, generated through variation, are kept as the new basis. For example, Myra may try varying her dishes, either intentionally or accidentally, and then decide on whether to update the dish with those variations. Effectuation theory states that the entrepreneur, as the pilot-in-the-plane, makes these updating decisions based on the available information at that time. Genetic algorithms teach us about the speed of updating processes and indicate that the decisions on building blocks should be neither too fast nor too slow. A decision that takes too long would imply a waste of resources on building blocks that fail to produce eventually, likely at the cost of investing in those that are productive. However, weeding out (combinations of) building blocks too quickly fails to provide the time for the building blocks to develop and become productive. Furthermore, building blocks cannot be put away deterministically with respect to the rate of introducing new ones, because if so, the diversity needed to create improvements disappears, and the success rate falls into local improvement. Many seasoned entrepreneurs clearly know the importance of allowing time and patience before making final decisions about the experimentation in which they engaged. Thus, we anticipate an inverted U-shaped relationship between the time taken for selection and design fitness.

As soon as Myra started a restaurant, alongside her catering business, she chose to focus on drawing in discovery-driven clients. She plans to introduce a new dish every other day, and if the new dish does not sell well in those 2 days, she will remove it. In reality though, if a dish does not perform well, Myra often takes weeks to adjust it and changes a dish only if it fails consistently for 2 weeks. The reason for this lengthened elimination decision is that only one chef works at the restaurant, so the speed of generating new dishes is relatively slow. However, to draw in clients, Myra realizes she has a large collection of Indian music and can experiment with different songs; she does not hesitate to stop the song if it fails to appeal to customers, even after just a few seconds. Therefore, she adjusts the speed of her selection decisions to the time required, such as the period needed to develop a new dish.

Yet the speed of updating the building blocks is interdependent with the severity of these decisions and is dependent on the amount of variation created. Thus, selection must align with the rate of introducing changes and variations. Change is valuable for innovation and entrepreneurship, so a higher frequency of change might appear preferable. Moreover, a high mutation rate early on is helpful to get out of local maxima. However, mutation rates also can be too high, as research in both genetic algorithms and biology shows (e.g., DomingoCalap and Sanjuán 2011; Elena and Sanjuán 2005; Gordo and Sousa 2010). The occurrences of mutation and recombination that increase fitness are far less frequent than those that decrease it. If the rate of change is too high and many changes occur together, entrepreneurs cannot effectively remove underperforming building blocks (i.e., abort and change some of their venturing experimentation) in favor of better ones. Because the detrimental changes cannot be weeded out in time if the rate of change is too high, the selection mechanism needs to be adjusted. In contrast, if the selection is too fast with respect to the rate of change, new ideas are not given enough time to evolve before they are judged, likely leading to biases against new and risky changes. 
Ventures with such unbalanced mechanisms tend to develop a culture contrary to changes (Denrell and March 2001).

For Myra's discovery-driven clients, the ambience of her new restaurant, including visual and acoustic effects, is a key design factor. To alter the acoustic effect, Myra simply changes her CDs; to alter the visual effect, she would need to redecorate, which represents a much slower process. Therefore, if a song is not generating its desired effect, Myra quickly pulls out another option from her large collection of Indian music. Conversely, Myra would only change the decor if she becomes totally convinced, from feedback from many clients, of the need for change, because it takes much longer to get the decoration right.

Design principle 4a: Align selectivity with the rate of change and severity of change.

Design principle $4 b$ : Align selection decision speed with the rate of change and severity of change.

Table 2 contains an overview of all the design principles related to the genetic algorithm steps, linking the new and existing effectual principles and illustrating the new ones with examples. In the iterative genetic algorithm-based design process, these design principles become inherently interrelated, consistent, and collectively independent (Romme and Endenburg 2006). That is, the design principles are interrelated because they cooperate iteratively in the four-step evolutionary process (e.g., without decomposition, there is no population of building blocks). Some design principles coordinate with other design principles, such as principle 4 .

\section{Discussion}

Despite calls to advance entrepreneurship research as a science of the artificial or design science (e.g., Dimov 2016; Van Burg and Romme 2014; Venkataraman et al. 2012; Sarasvathy 2003), progress has been limited. Developing good design principles is crucial to gain the understanding of the mechanisms through which entrepreneurs design their ventures as well as to guide entrepreneurs in these design processes. Developing design principles is challenging, but because the principles of good design are generic, nonproblem-specific, and invariant across domains, entrepreneurship can borrow design principles from other design fields through analogous transfer - a practice common in many design sciences such as artificial intelligence (Bate and Robert 2007; Miller et al. 2002). Therefore, we borrowed several design principles from genetic algorithms as an artificial intelligence design theory that shares fundamental characteristics with management in general and entrepreneurship in particular. In doing so, this article makes several contributions.

\subsection{Developing entrepreneurship as a design science}

This study helps substantiate an approach to develop entrepreneurship as a science of the artificial. In fact, as a field, we know little about the approaches to fulfill the promise of developing entrepreneurship as a science of the artificial (cf. Venkataraman et al. 2012). Our approach to develop design principles uses analogous transfer from other design sciences, which inevitably introduces new concepts and vocabularies for entrepreneurship and effectuation scholars. However, these new vocabularies carry the potential to further enrich entrepreneurship and management theory. In performing an analogous transfer from a distant field such as genetic algorithms, we shed light on how future research might similarly cross-fertilize from other design fields to shape the "world as it might be" for entrepreneurship as a science of the artificial (Sarasvathy et al. 2008). In our field, this approach is rarely used, which may be due to the different vocabularies and different (prescriptive vs. positivist) design traditions (Van Burg and Romme 2014). We hope this initial effort opens the door for more cross-pollination for entrepreneurship from other sciences, particularly other evolutionary artificial intelligence design techniques. This approach of borrowing could help to develop not just high-level design principles but also design elements and approaches for entrepreneurship theory and practice.

Design principles from an important link between the scientific body of knowledge and practice (Berglund et al. 2018; Romme 2003), and entrepreneurs can apply the principles we developed to design new ventures. Thus, our study reconnects to Herbert Simon's notion of design as a science of the artificial concerned with the "world as it might be" (Sarasvathy et al. 2008). Simon's notion is crucial for advancing entrepreneurship as a design science (Dimov 2016), to prescribe real help for entrepreneurs (Sarasvathy and Venkataraman 2011). In the same vein, this study shows how to develop 
principles that offer prescriptions and, in doing so, helps bridge the gap between descriptive academic research and entrepreneurial practice.

\subsection{Advancing effectuation theory}

This article contributes to effectuation theory in two critical ways: its theoretical refinement as a design science (e.g., Arend et al. 2015; Read et al. 2016; Venkataraman et al. 2012) and its provision of useful prescriptions for designing effectuation processes (e.g., Sarasvathy 2001, 2008). Specifically, this article provides new and complementary design principles for effectuation - a critical challenge for effectuation to grow as a design science (Sarasvathy and Dew 2005). Our new design principles pertain to crucial issues in effectuation theory, such as how to deal with variation, how to select means, and at what moment. Such key issues are faced by effectuators and puzzle entrepreneurship scholars, but they have not been specified yet in the initial set of five effectual design principles.

Table 3 illustrates how the identified principles augment extant effectuation principles and enrich effectual design processes. In particular, we provide more guidance on the means that entrepreneurs can use to build their ventures (Arend et al. 2015; Chiles et al. 2008; Read et al.

Table 3 Design principles for effectual design, based on genetic algorithms

\begin{tabular}{|c|c|c|c|c|}
\hline Step & New design principles & Links to existing principles & Myra's example & Real-world examples \\
\hline Initiation & $\begin{array}{l}\text { 1. Gather more than just } \\
\text { a few means; at the same } \\
\text { time, it is more important } \\
\text { to have more diverse means } \\
\text { than merely more means. }\end{array}$ & $\begin{array}{l}\text { Related to the first and } \\
\text { third effectuation principles, } \\
\text { the idea of beginning with } \\
\text { what one has at hand or in } \\
\text { the hands of stakeholders, } \\
\text { adding that diversity of the } \\
\text { initial set of means is crucial. }\end{array}$ & $\begin{array}{l}\text { Myra does not start with } \\
\text { all her means or just } \\
\text { one means but with a } \\
\text { little bit of everything. }\end{array}$ & $\begin{array}{l}\text { The founder of the } \\
\text { green energy start-up } \\
\text { SunCo explores } \\
\text { various means to use } \\
\text { "green" energy, such } \\
\text { as wind, solar-thermal, } \\
\text { and PV-solar (Reymen } \\
\text { et al. 2015). }\end{array}$ \\
\hline Selection & $\begin{array}{l}\text { 2. Use one or more } \\
\text { fast-and-frugal tests (i.e., } \\
\text { substantial convergence } \\
\text { in the population, } \\
\text { sufficient quality, time } \\
\text { elapsed since last } \\
\text { improvement) to select } \\
\text { appropriate building } \\
\text { blocks for new } \\
\text { venture creation. }\end{array}$ & $\begin{array}{l}\text { Related to the affordable loss } \\
\text { principle and to the } \\
\text { principle of co-adapting } \\
\text { with pre-committed } \\
\text { stakeholders, but adding } \\
\text { more specific selection } \\
\text { principles. }\end{array}$ & $\begin{array}{l}\text { Myra uses fast-and-frugal } \\
\text { tests to figure out } \\
\text { which means and } \\
\text { combinations of } \\
\text { means work and } \\
\text { which do not. }\end{array}$ & $\begin{array}{l}\text { Lean start-up tests, such } \\
\text { as "If we cannot } \\
\text { improve a certain } \\
\text { technology after } \\
\text { working on it for half } \\
\text { a year, we move on to } \\
\text { other technologies." }\end{array}$ \\
\hline Variation & $\begin{array}{l}\text { 3. Decompose by } \\
\text { constructing multiple } \\
\text { representations to } \\
\text { identify building blocks } \\
\text { and subsequently } \\
\text { explore new } \\
\text { combinations by } \\
\text { exchanging building } \\
\text { blocks. }\end{array}$ & $\begin{array}{l}\text { Related to the third and fourth } \\
\text { effectuation principles, but } \\
\text { specifying the process of } \\
\text { decomposition in } \\
\text { effectuation theory } \\
\text { (Sarasvathy 2003, 2008). }\end{array}$ & $\begin{array}{l}\text { Myra decomposes her } \\
\text { new venture based } \\
\text { on several perspectives, } \\
\text { resulting in the insight } \\
\text { that buying food and } \\
\text { materials can be } \\
\text { improved by engaging } \\
\text { with a friend. }\end{array}$ & $\begin{array}{l}\text { The popular business } \\
\text { model canvases aim } \\
\text { to help decompose } \\
\text { and evolve new } \\
\text { ventures according } \\
\text { to its different } \\
\text { elements. }\end{array}$ \\
\hline $\begin{array}{r}\text { Retention (and } \\
\text { elimination) }\end{array}$ & $\begin{array}{l}\text { 4a. Align selectivity } \\
\text { with the rate of change } \\
\text { and severity of change. } \\
\text { 4b. Align selection } \\
\text { decision speed with } \\
\text { the rate of change } \\
\text { and severity of change. }\end{array}$ & $\begin{array}{l}\text { Related to the pilot-in-the-plane } \\
\text { principle, describing that } \\
\text { given the level of } \\
\text { uncertainty, the entrepreneur } \\
\text { needs to collect information } \\
\text { about the performance of } \\
\text { the means. These additional } \\
\text { principles describe key levers } \\
\text { that entrepreneurs (could) } \\
\text { use to design their } \\
\text { entrepreneurial endeavors. }\end{array}$ & $\begin{array}{l}\text { Myra gives her effectual } \\
\text { experiments time to } \\
\text { develop but will } \\
\text { move on from those } \\
\text { means if they fail to } \\
\text { achieve certain quality } \\
\text { over time. }\end{array}$ & $\begin{array}{l}\text { Google runs experiments } \\
\text { with new technologies, } \\
\text { but it is very } \\
\text { disciplined about } \\
\text { terminating projects if } \\
\text { they do not show } \\
\text { much progress after } \\
\text { a certain time. }\end{array}$ \\
\hline
\end{tabular}


2016), highlighting the relevance of a diverse yet reasonable amount of means. The newly identified principle 1 reveals that the set of means should be primarily diverse and does not necessary to be a large set. The recognition that the diversity of means is important highlights an overlooked aspect of effectuation, moving effectuation beyond merely starting from means to the question which means represent better starting points.

The differentiation of better means to start with can offer theoretical insights that may explain the lack of consistent results on the relative effects of a means-driven orientation (e.g., Brettel et al. 2012; Read et al. 2009). These inconsistent results may be due to failures to discriminate between well-populated, diverse sets of means and overpopulated sets that lack diversity. Such differences lead to differential performance, such that entrepreneurs with more diverse sets of means achieve better performance than those with an abundance of one particular means, such as capital (e.g., Dolmans et al. 2014). In addition, the new principles 2 and 3 indicate how entrepreneurs can co-adapt their means in an evolutionary process. Together, these principles suggest the diversity and size of the population and selection of means as important avenues for future effectuation research.

Moreover, design principle 4 issues clear prescriptions for moving on from certain means. Prior effectuation research suggests that people tend to continue expanding the set of means (Read and Dolmans 2012) but offers little guidance on how to deal with unsatisfying means. Our newly identified principles provide more guidance on the generation of variety and the selection of variants than the initial set of five principles do. While the initial set of principles generically treats variants as a contingency to exploit and fails to guide on when to move on from certain means, our newly identified principles 3 and 4 offer guidance on the most important issues regarding variation and retention to distinguish what are good means. Moreover, these principles provide guidance regarding an important temporal issue in effectuation (cf. Jiang and Rüling 2018), namely, the speed at which variants need to be introduced and eliminated.

The newly identified design principles address critical but so far often untouched questions that entrepreneurs face in designing their ventures, including which means to start with, how to select the means in relation to their performance over time, how to identify and create new means, and how to balance the pace and selectivity of attaining new means and eliminating subperforming ones. These questions are untouched in the literature to date, but even simple awareness of these design questions would help frame entrepreneurs' minds and enhances designers' learning capability, along with the effectiveness of their actions (cf. Romme and Endenburg 2006), and the new principles guide entrepreneurs in their decision-making in several key design questions.

\subsection{Learning from AI: further research}

Entrepreneurship, AI, and big data are all relatively new and fast-growing disciplines. The fields of big data and AI deal with huge amounts of information and have focused on developing fast-and-frugal tests, and accordingly, they offer potential lessons to the entrepreneurship field via analogous transfer or cross-pollination. First, genetic algorithms and other evolutionary metaheuristics seem particularly helpful for furthering entrepreneurship theories, both theoretically and practically. For example, big data and AI may shed light on the design principles of bricolage (Baker and Nelson 2005) or theories on opportunity creation and discovery (Alvarez and Barney 2007).

Second, the design principles we identified are highlevel design principles, just like the initial set of five effectual principles of Sarasvathy (2001). Therefore, it would be worthwhile to develop additional design principles by analogous transfer from $\mathrm{AI}$ around the processes of crossover and mutation, along the lines of the nine forms of transformation as identified by Dew et al. (2011).

Third, the additional principles based on genetic algorithms can be formulated readily as novel and intriguing empirical research questions. For example, does nondeterministic fast-and-frugal test lead to better venture designs than other forms of evaluation do? It is important to note that as in good design, the design principles form an interrelated system and cannot be tested as completely independent propositions, due to the importance of their interdependencies (CaspinWagner et al. 2013). A system approach is necessary for the theoretical and empirical development of these design principles. In this respect, an integrative model to simulate the entrepreneurship process would be helpful (Davis et al. 2007; McKelvey 2004).

Fourth, although these principles cohere theoretically in the iterative, four-step genetic algorithm process, the coherency can be further improved by future work that puts the principles into practice (cf. Van Burg et al. 2008). Thus, the coherence of the design principles requires testing, and recent work on measuring ideas in 
entrepreneurship (e.g., Hill and Birkinshaw 2010) may help in this regard.

Finally, the fields of AIs and big data develop computational models to handle large amount of information nondeterministically, and they can be applied literally as decision support systems for people running new ventures or innovation projects (cf. Dellermann et al. 2018; Sohn and Lee 2013; Zhang and Babovic 2011, 2012). Future studies can explore how entrepreneurs can use AI nondeterministic models as decision support for pathdependent decision-making under uncertainty.

\section{Conclusions}

The challenge of advancing entrepreneurship as a design science promises to aid entrepreneurs in making key design decisions and, at the same time, contributes to theory building. Yet the challenge is massive and daunting, requiring new approaches. With a cross-pollination approach from an artificial intelligence field, this study helps entrepreneurship - and effectuation theory in particular - by generating design principles to substantiate the development as a nascent design science. The identification of design principles represents an initial foundational step; we invite others to join the study of entrepreneurship as a science of what can be. This early study is inevitably speculative and different, but we hope it is also provocative, helpful, and enriching, in terms of both theoretical development and practical guidance.

Open Access This article is distributed under the terms of the Creative Commons Attribution 4.0 International License (http:// creativecommons.org/licenses/by/4.0/), which permits unrestricted use, distribution, and reproduction in any medium, provided you give appropriate credit to the original author(s) and the source, provide a link to the Creative Commons license, and indicate if changes were made.

\section{References}

Aldrich, H. E., \& Martinez, M. A. (2001). Many are called, but few are chosen: an evolutionary perspective for the study of entrepreneurship. Entrepreneurship: Theory and Practice, 25(4), 41-56. https://doi.org/10.1177/104225870102500404.

Alvarez, S. A., \& Barney, J. B. (2007). Discovery and creation: alternative theories of entrepreneurial action. Strategic Entrepreneurship Journal, 1(1-2), 11-26. https://doi. org/10.1002/sej.4.
Alvarez, S. A., Barney, J. B., \& Anderson, P. (2013). Forming and exploiting opportunities: the implications of discovery and creation processes for entrepreneurial and organizational research. Organization Science, 24(1), 301-317. https://doi. org/10.1287/orsc. 1110.0727 .

Andreoni, J., \& Miller, J. H. (1995). Auctions with artificial adaptive agents. Games and Economic Behavior, 10(1), 3964. https://doi.org/10.1006/game.1995.1024.

Arend, R. J., Sarooghi, H., \& Burkemper, A. (2015). Effectuation as ineffectual? Applying the $3 \mathrm{E}$ theory assessment framework to a proposed new theory of entrepreneurship. Academy of Management Review, 40(4), 630-651. https://doi. org/10.5465/amr.2014.0455.

Arifovic, J. (1995). Genetic algorithms and inflationary economies. Journal of Monetary Economics, 36(1), 219-243. https://doi.org/10.1016/0304-3932(95)01203-7.

Arifovic, J., \& Bullard, J. (1997). The transition from stagnation to growth: an adaptive learning approach. Development, 2(2), 185-209. https://doi.org/10.1023/A:1009733218546.

Augier, M., \& Teece, D. J. (2009). Dynamic capabilities and the role of managers in business strategy and economic performance. Organization Science, 20(2), 410-421. https://doi. org/10.1287/orsc. 1090.0424 .

Baker, T., \& Nelson, R. E. (2005). Creating something from nothing: resource construction through entrepreneurial bricolage. Administrative Science Quarterly, 50(3), 329-366. https://doi.org/10.2189/asqu.2005.50.3.329.

Baldwin, C. Y., \& Clark, K. B. (2000). Design rules: the power of modularity. Cambridge, MA: The MIT Press.

Baron, J. N., Burton, M. D., \& Hannan, M. T. (1999). Engineering bureaucracy: the genesis of formal policies, positions, and structures in high-technology firms. The Journal of Law, Economics, and Organization, 15(1), 1-41. https://doi. org/10.1093/jleo/15.1.1.

Baron, J. N., Hannan, M. T., \& Burton, M. D. (2001). Labor pains: change in organizational models and employee turnover in young, high-tech firms. American Journal of Sociology, 106(4), 960-1012. https://doi.org/10.1086/320296.

Bate, P., \& Robert, G. (2007). Toward more user-centric OD: lessons from the field of experience-based design and a case study. The Journal of Applied Behavioral Science, 43(1), 4166. https://doi.org/10.1177/0021886306297014.

Berglund, H., Dimov, D., \& Wennberg, K. (2018). Beyond bridging rigor and relevance: the three-body problem in entrepreneurship. Journal of Business Venturing Insights, 9, 87-91. https://doi.org/10.1016/j.jbvi.2018.02.001.

Breslin, D. (2008). A review of the evolutionary approach to the study of entrepreneurship. International Journal of Management Reviews, 10(4), 399-423. https://doi. org/10.1111/j.1468-2370.2008.00234.x.

Brettel, M., Mauer, R., Engelen, A., \& Küper, D. (2012). Corporate effectuation: entrepreneurial action and its impact on R\&D project performance. Journal of Business Venturing, 27, 167-184. https://doi.org/10.1016/j.jbusvent.2011.01.001.

Bruderer, E., \& Singh, J. V. (1996). Organizational evolution, learning, and selection: a genetic-algorithm-based model. Academy of Management Journal, 39(5), 1322-1349. https://doi.org/10.5465/257001.

Caspin-Wagner, K., Lewin, A. Y., Massini, S., \& Peeters, C. (2013). The underexplored role of managing interdependencies fit in organization design and performance. Journal 
of Organization Design, 2(1), 34 41. https://doi.org/10.7146 jod.7998.

Cavarretta, F. L., \& Furr, N. R. (2013). Which entrepreneurship paradigm? Exploring the epistemic properties of keystone rules. Academy of Management Proceedings, 13633. doi: https://doi.org/10.5465/ambpp.2013.13633abstract.

Chandler, G. N., DeTienne, D. R., McKelvie, A., \& Mumford, T. V. (2011). Causation and effectuation processes: a validation study. Journal of Business Venturing, 26(3), 375-390. https://doi.org/10.1016/j.jbusvent.2009.10.006.

Chattoe-Brown, E. (1998). Just how (un)realistic are evolutionary algorithms as representations of social processes? Journal of Artificial Societies and Social Simulation, 1(3), 311-354.

Chaudhry, S. S., \& Luo, W. (2005). Application of genetic algorithms in production and operations management: a review. International Journal of Production Research, 43(19), 40834101. https://doi.org/10.1080/00207540500143199.

Cheng, C. D., \& Kosorukoff, A. (2004). Interactive one-max problem allows to compare the performance of interactive and human-based genetic algorithms. In Genetic and evolutionary computation conference (pp. 983-993). Springer. doi:https://doi.org/10.1007/978-3-540-24854-5_98.

Chiles, T. H., Gupta, V. K., \& Bluedorn, A. C. (2008). On Lachmannian and effectual entrepreneurship: a rejoinder to Sarasvathy and Dew (2008). Organization Studies, 29(2), 247-253. https://doi.org/10.1177/0170840607088154.

Cornelissen, J. P., \& Durand, R. (2014). Moving forward: developing theoretical contributions in management studies. Journal of Management Studies, 51(6), 995-1022. https://doi.org/10.1111/joms.12078.

Crawford, G. C., \& Kreiser, P. M. (2015). Corporate entrepreneurship strategy: extending the integrative framework through the lens of complexity science. Small Business Economics, 1-21. https://doi.org/10.1007/s11187-015-9637-1.

Cross, N. (2001). Designerly ways of knowing: design discipline versus design science. Design Issues, 17(3), 49-55. https://doi.org/10.1162/074793601750357196.

Davis, J., Eisenhardt, K. M., \& Bingham, C. (2007). Developing theory through simulation methods. Academy of Management Review, 32(2), 480-499. https://doi. org/10.5465/amr.2007.24351453.

Dellermann, D., Lipusch, N., Ebel, P., \& Leimeister, J. M. (2018). Design principles for a hybrid intelligence decision support system for business model validation. Electronic Markets, 119. https://doi.org/10.1007/s12525-018-0309-2.

Denrell, J., \& March, J. G. (2001). Adaptation as information restriction: the hot stove effect. Organization Science, 12(5), 523-538. https://doi.org/10.1287/orsc.12.5.523.10092.

Denyer, D., Tranfield, D., \& Van Aken, J. E. (2008). Developing design propositions through research synthesis. Organization Studies, 29(3), 393-413. https://doi.org/10.1177 /0170840607088020.

Dew, N., Read, S., Sarasvathy, S. D., \& Wiltbank, R. (2009). Effectual versus predictive logics in entrepreneurial decision-making: Differences between experts and novices. Journal of Business Venturing, 24(4), 287-309. https://doi. org/10.1016/j.jbusvent.2008.02.002.

Dew, N., Read, S., Sarasvathy, S. D., \& Wiltbank, R. (2011). On the entrepreneurial genesis of new markets: effectual transformations versus causal search and selection. Journal of
Evolutionary Economics, 21(2), 231-253. https://doi. org/10.1007/s00191-010-0185-1.

Dew, N., Read, S., Sarasvathy, S. D., \& Wiltbank, R. E. (2018). Microfoundations for new market creation: differences between expert entrepreneurs and expert managers. International Review of Entrepreneurship, 16(1), 1-28.

Dew, N., Sarasvathy, S. D., \& Venkataraman, S. (2004). The economic implications of exaptation. Journal of Evolutionary Economics, 14(1), 69-84. https://doi. org/10.1007/s00191-003-0180-x.

Dimov, D. (2016). Toward a design science of entrepreneurship. In Models of start-up thinking and action: theoretical, empirical and pedagogical approaches (pp. 1-31). Emerald Group Publishing Limited.

Dolmans, S. A. M., Van Burg, E., Reymen, I. M. M. J., \& Romme, A. G. L. (2014). Dynamics of resource slack and constraints: resource positions in action. Organization Studies, 35(4), 511-549. https://doi.org/10.1177/0170840613517598.

Domingo-Calap, P., \& Sanjuán, R. (2011). Experimental evolution of RNA versus DNA viruses. Evolution, 65(10), 2987-2994. https://doi.org/10.1111/j.1558-5646.2011.01339.x.

Eccles, J. S., \& Wigfield, A. (2002). Motivational beliefs, values, and goals. Annual Review of Psychology, 53(1), 109-132. https://doi.org/10.1146/annurev.psych.53.100901.135153.

Elena, S. F., \& Sanjuán, R. (2005). Adaptive value of high mutation rates of RNA viruses: separating causes from consequences. Journal of Virology, 79(18), 11555-11558. https://doi.org/10.1128/JVI.79.18.11555-11558.2005.

Engel, Y., Van Burg, E., Kleijn, E., \& Khapova, S. (2017). Past career in future thinking: how career management practices shape entrepreneurial decision-making. Strategic Entrepreneurship Journal, 11(2), 122-144. https://doi. org/10.1002/sej.1243.

Fisher, G. (2012). Effectuation, causation, and bricolage: a behavioral comparison of emerging theories in entrepreneurship research. Entrepreneurship Theory and Practice, 36(5), 1019-1051. https://doi.org/10.1111/j.1540-6520.2012.00537.x.

Fuller, R. B. (n.d.). Fuller on Design Science. https://www.bfi. org/design-science/primer/fuller-design-science. Accessed 13 July 2018.

Fuller, R. B. (1969). Utopia or oblivion: the prospects for humanity. New York: Bantam Books.

Garbuio, M., Dong, A., Lin, N., Tschang, F., \& Lovallo, D. (2017). Demystifying the genius of entrepreneurship: how design cognition can help create the next generation of entrepreneurs. The Academy of Management Learning and Education. https://doi.org/10.5465/amle.2016.0040.

Garud, R., Kumaraswamy, A., \& Sambamurthy, V. (2006). Emergent by design: performance and transformation at Infosys Technologies. Organization Science, 17(2), 277286. https://doi.org/10.1287/orsc.1050.0179.

Goldberg, D. (2002). The design of innovation (genetic algorithms and evolutionary computation) (p. 272). Boston: Springer.

Goldberg, D. E. (1989). Genetic algorithms in search, optimization and machine learning. Boston, MA: Addison-Wesley Professional.

Goldberg, D. E. (2000). The design of innovation: lessons from genetic algorithms, lessons for the real world. Technological Forecasting and Social Change, 64(1), 7-12. https://doi. org/10.1016/S0040-1625(99)00079-7. 
Gordo, I., \& Sousa, A. (2010). Mutation, selection and genetic interactions in bacteria. In Encyclopedia of life sciences. Chichester: John Wiley \& Sons. https://doi.org/10.1002 /9780470015902.a0022175.

Henrich, J., Boyd, R., \& Richerson, P. J. (2008). Five misunderstandings about cultural evolution. Human Nature, 19(2), 119-137. https://doi.org/10.1007/s12110-008-9037-1.

Heusinkveld, S., Benders, J., \& Hillebrand, B. (2013). Stretching concepts: the role of competing pressures and decoupling in the evolution of organization concepts. Organization Studies, 34(1), 7-32. https://doi.org/10.1177/0170840612464748.

Hevner, A. R., March, S. T., Park, J., \& Ram, S. (2004). Design science in information systems research. MIS Quarterly, 28(1), 75-105.

Hill, S. A., \& Birkinshaw, J. M. (2010). Idea sets: conceptualizing and measuring a new unit of analysis in entrepreneurship research. Organizational Research Methods, 13(1), 85-113. https://doi.org/10.1177/1094428109337542.

Hodgson, G. M. (2013). Understanding organizational evolution: toward a research agenda using generalized Darwinism. Organization Studies, 34(7), 973-992. https://doi. org/10.1177/0170840613485855.

Holland, J. (1975). Adaption in natural and artificial systems. Artificial life (1992nd ed.). Cambridge, MA: MIT Press. https://doi.org/10.1162/1064546053278919.

Jelinek, M., Romme, A. G. L., \& Boland, R. J. (2008). Introduction to the special issue: organization studies as a science for design: creating collaborative artifacts and research. Organization Studies, 29(3), 317-329. https://doi. org/10.1177/0170840607088016.

Jiang, Y., \& Rüling, C.-C. (2018). Opening the black box of effectuation processes: characteristics and dominant types. Entrepreneurship Theory and Practice, Forthcoming. https://doi.org/10.1177/1042258717744204.

Knight, F. H. (1921). Risk, uncertainty and profit. New York: Hart, Schaffner and Marx.

Kogut, B., \& Kulatilaka, N. (2001). Capabilities as real options. Organization Science, 12(6), 744-758. https://doi. org/10.1287/orsc.12.6.744.10082.

Kosorukoff, A. (2001). Human based genetic algorithm. In 2001 IEEE International Conference on Systems Man and Cybernetics (Vol. 5, pp. 3464-3469). Tucson, AZ. https://doi.org/10.1109/ICSMC.2001.972056.

Kreng, V. B., \& Lee, T.-P. (2004). Modular product design with grouping genetic algorithm: a case study. Computers \& Industrial Engineering, 46(3), 443-460. https://doi. org/10.1016/j.cie.2004.01.007.

Lee, J., Lee, K., \& Rho, S. (2002). An evolutionary perspective on strategic group emergence: a genetic algorithm-based model. Strategic Management Journal, 23(8), 727-746. https://doi. org/10.1002/smj.250.

Luo, J. (2015). The united innovation process: integrating science, design, and entrepreneurship as sub-processes. Design Science, 1(2), 1-29. https://doi.org/10.1017/dsj.2015.2.

Matthews, J. H. (2009). What are the lessons for entrepreneurship from creativity and design? In Proceedings of the 2009 Academy of Management Annual Meeting. Chicago, IL: Academy of Management.

McKelvey, B. (2004). Toward a complexity science of entrepreneurship. Journal of Business Venturing, 19(3), 313-341. https://doi.org/10.1016/S0883-9026(03)00034-X.
Miller, J. F., Kalganova, T., Job, D., \& Lipnitkaya, N. (2002). The genetic algorithm as a discovery engine: strange circuits and new principles. In P. J. Bentley \& D. W. Corne (Eds.), Creative evolutionary systems (pp. 443-466). San Francisco: Morgan Kaufmann Publishers. https://doi. org/10.1016/B978-155860673-9/50058-6.

Ocasio, W. (1997). Towards an attention-based view of the firm. Strategic Management Journal, 18(S1), 187-217. https://doi. org/10.1002/(SICI)1097-0266(199707)18:1+<187::AIDSMJ936>3.0.CO;2-K.

Oswick, C., Fleming, P., \& Hanlon, G. (2011). From borrowing to blending: Rethinking the processes of organizational theory building. Academy of Management Review, 36(2), 318-337. https://doi.org/10.5465/AMR.2011.59330932.

Parrish, B. D. (2010). Sustainability-driven entrepreneurship: principles of organization design. Journal of Business Venturing, 25(5), 510-523. https://doi.org/10.1016/j. jbusvent.2009.05.005.

Pandza, K., \& Thorpe, R. (2010). Management as design, but what kind of design? An appraisal of the design science analogy for management. British Journal of Management, 21(1), 171-186. https://doi.org/10.1111/j.1467-8551.2008.00623.x.

Perry, J. T., Chandler, G. N., \& Markova, G. (2012). Entrepreneurial effectuation: a review and suggestions for future research. Entrepreneurship Theory and Practice, 36(4), 837-861. https://doi.org/10.1111/j.15406520.2010.00435.x.

Plsek, P., Bibby, J., \& Whitby, E. (2007). Practical methods for extracting explicit design rules grounded in the experience of organizational managers. The Journal of Applied Behavioral Science, 43(1), 153-170. https://doi.org/10.1177 /0021886306297013.

Read, S., \& Dolmans, S. A. M. (2012). Effectuation 10 year waypoint. International Review of Entrepreneurship, 10(1), $1-22$.

Read, S., Sarasvathy, S. D., Dew, N., \& Wiltbank, R. E. (2016). Response to Arend, Sarooghi, and Burkemper (2015): cocreating effectual entrepreneurship research. Academy of Management Review, 41(3), 528-536. https://doi. org/10.5465/amr.2015.0180.

Read, S., Song, M., \& Smit, W. (2009). A meta-analytic review of effectuation and venture performance. Journal of Business Venturing, 24(6), 573-587. https://doi.org/10.1016/j. jbusvent.2008.02.005.

Ren, J., Nickerson, J. V., Mason, W., Sakamoto, Y., \& Graber, B. (2014). Increasing the crowd's capacity to create: how alternative generation affects the diversity, relevance and effectiveness of generated ads. Decision Support Systems, 65(2014), 28-39. https://doi.org/10.1016/j.dss.2014.05.009.

Reymen, I. M. M. J., Andries, P., Berends, H., Mauer, R., Stephan, U., \& Van Burg, E. (2015). Understanding dynamics of strategic decision making in venture creation: a process study of effectuation and causation. Strategic Entrepreneurship Journal, 9(4), 351-379. https://doi.org/10.1002/sej.1201.

Ries, E. (2011). The lean startup: how today's entrepreneurs use continuous innovation to create radically successful businesses. New York: Crown Publishing Group.

Rivkin, J. W., \& Siggelkow, N. (2003). Balancing search and stability: interdependencies among elements of organizational design. Management Science, 49(3), 290-311. https://doi. org/10.1287/mnsc.49.3.290.12740. 
Romme, A. G. L. (2003). Making a difference: organization as design. Organization Science, 14(5), 558-573. https://doi. org/10.1287/orsc.14.5.558.16769.

Romme, A. G. L., \& Endenburg, G. (2006). Construction principles and design rules in the case of circular design. Organization Science, 17(2), 287-297. https://doi. org/10.1287/orsc.1050.0169.

Sarasvathy, S. D. (2001). Causation and effectuation: toward a theoretical shift from economic inevitability to entrepreneurial contingency. Academy of Management Review, 26(2), 243-263. https://doi.org/10.5465/amr.2001.4378020.

Sarasvathy, S. D. (2003). Entrepreneurship as a science of the artificial. Journal of Economic Psychology, 24(2), 203-220. https://doi.org/10.1016/S0167-4870(02)00203-9.

Sarasvathy, S. D. (2004). Making it happen: beyond theories of the firm to theories of firm design. Entrepreneurship Theory and Practice, 28(6), 519-531. https://doi.org/10.1111/j.15406520.2004.00062.x.

Sarasvathy, S. D. (2008). Effectuation: elements of entrepreneurial expertise. Northampton, MA, US: Edward Elgar Pub. dx. https://doi.org/10.4337/9781848440197.

Sarasvathy, S. D., \& Dew, N. (2005). New market creation through transformation. Journal of Evolutionary Economics, 15(5), 533-565. https://doi.org/10.1007/s00191-005-0264-X.

Sarasvathy, S. D., Dew, N., Read, S., \& Wiltbank, R. (2008). Designing organizations that design environments: lessons from entrepreneurial expertise. Organization Studies, 29(3), 331-350. https://doi.org/10.1177/0170840607088017.

Sarasvathy, S. D., Read, S., Dew, N., \& Wiltbank, R. (2010). Locus of variation in models of new market creation. London: Druid Summer Conference 2010.

Sarasvathy, S. D., \& Venkataraman, S. (2011). Entrepreneurship as method: open questions for an entrepreneurial future. Entrepreneurship Theory and Practice, 35(1), 113-135. https://doi.org/10.1111/j.1540-6520.2010.00425.x.

Sastry, K., \& Goldberg, D. E. (2003). Probabilistic model building and competent genetic programming. In Genetic programming theory and practice (pp. 205-220). Boston, MA: Springer. https://doi.org/10.1007/978-1-4419-8983-3_13.

Sastry, K., Goldberg, D. E., \& Kendall, G. (2005). Genetic algorithms. In E. K. Burke \& G. Kendall (Eds.), Search methodologies: introductory tutorials in optimization and decision support techniques (pp. 97-125). Boston, MA: Springer. https://doi.org/10.1007/0-387-28356-0_4.

Selden, P. D., \& Fletcher, D. E. (2015). The entrepreneurial journey as an emergent hierarchical system of artifactcreating processes. Journal of Business Venturing, 30(4), 603-615. https://doi.org/10.1016/j.jbusvent.2014.09.002.

Schmitt, A., Rosing, K., Zhang, S. X., \& Leatherbee, M. (2018). A dynamic model of entrepreneurial uncertainty and business opportunity identification: exploration as a mediator and entrepreneurial self-efficacy as a moderator. Entrepreneurship Theory and Practice, 42(6), 835-859. https://doi.org/10.1177/1042258717721482.

Simon, H. A. (1969). The sciences of the artificial. Cambridge: MIT Press.

Sohn, S. Y., \& Lee, A. S. (2013). Bayesian network analysis for the dynamic prediction of early stage entrepreneurial activity index. Expert Systems with Applications, 40(10), 4003-4009. https://doi.org/10.1016/j.eswa.2013.01.009.
Takagi, H. (2001). Interactive evolutionary computation: fusion of the capabilities of EC optimization and human evaluation. Proceedings of the IEEE, 89(9), 1275-1296. https://doi. org/10.1109/5.949485.

Teece, D. J., Pisano, G., \& Shuen, A. (1997). Dynamic capabilities and strategic management. Strategic Management Journal, 18(7), 509-533. https://doi.org/10.1002/(SICI)1097-0266 (199708)18:7<509::AID-SMJ882>3.0.CO;2-Z.

Tranfield, D., Denyer, D., \& Smart, P. (2003). Towards a methodology for developing evidence-informed management knowledge by means of systematic review. British Journal of Management, 14(3), 207-222. https://doi.org/10.1111/1467-8551.00375.

Van Aken, J. E. (2004). Management research based on the paradigm of the design sciences: the quest for field-tested and grounded technological rules. Journal of Management Studies, 41(2), 219-246. https://doi.org/10.1111/j.14676486.2004.00430.x.

Van Burg, E., \& Romme, A. G. L. (2014). Creating the future together: toward a framework for research synthesis in entrepreneurship. Entrepreneurship Theory and Practice, 38(2), 369-397. https://doi.org/10.1111/etap.12092.

Van Burg, E., Romme, A. G. L., Gilsing, V. A., \& Reymen, I. M. M. J. (2008). Creating university spin-offs: a science-based design perspective. Journal of Product Innovation Management, 25(2), 114-128. https://doi.org/10.1111 j.1540-5885.2008.00291.x.

Van de Ven, A. H. (2007). Engaged scholarship: a guide for organizational and social research. New York: Oxford University Press.

Vassolo, R. S., \& Anand, J. (2008). An examination of dynamic capabilities: is evolutionary theory underdetermined? Management Research, 6(1), 47-62. https://doi.org/10.2753 /JMR1536-5433060103.

Venkataraman, S., Sarasvathy, S. D., Dew, N., \& Forster, W. R. (2012). Reflections on the 2010 AMR decade award: whither the promise? Moving forward with entrepreneurship as a science of the artificial. Academy of Management Review, 37(1), 21-33. https://doi.org/10.5465/amr.2011.0079.

Wasserman, N. (2012). The founder's dilemmas: anticipating and avoiding the pitfalls that can sink a startup. Princeton, NJ: Princeton University Press.

Weeks, J., \& Galunic, C. (2003). A theory of the cultural evolution of the firm: the intra-organizational ecology of memes. Organization Studies, 24(8), 1309-1352. https://doi. org/10.1177/01708406030248005.

Wiltbank, R., Dew, N., Read, S., \& Sarasvathy, S. D. (2006). What to do next? The case for non-predictive strategy. Strategic Management Journal, 27(10), 981-998. https://doi. org/10.1002/smj.555.

Wiltbank, R., Read, S., Dew, N., \& Sarasvathy, S. D. (2009). Prediction and control under uncertainty: outcomes in angel investing. Journal of Business Venturing, 24(2), 116-133. https://doi.org/10.1016/j.jbusvent.2007.11.004.

Zang, H., Zhang, S., \& Hapeshi, K. (2010). A review of natureinspired algorithms. Journal of Bionic Engineering, 7, S232S237. https://doi.org/10.1016/S1672-6529(09)60240-7.

Zhang, S. X., \& Babovic, V. (2011). An evolutionary real options framework for design and management of large-scale projects and systems with multiple real options. Decision Support Systems, 5(11), 119-129. https://doi.org/10.1016/j. dss.2010.12.001. 
Zhang, S. X., \& Babovic, V. (2012). A real options approach to the design and architecture of water supply systems using innovative water technologies under uncertainty. Journal of Hydroinformatics, 14(1), 13-29. https://doi.org/10.2166 /hydro.2011.078.

Zimmerman, B. J. (2002). Becoming a self-regulated learner: an overview. Theory Into Practice, 41(2), 64-70. https://doi. org/10.1207/s15430421tip4102_2.
Zott, C. (2002). When adaptation fails: an agent-based explanation of inefficient bargaining under private information. Journal of Conflict Resolution, 46(6), 727-753. https://doi. org/10.1177/002200202237927.

Publisher's note Springer Nature remains neutral with regard to jurisdictional claims in published maps and institutional affiliations. 